\title{
Food web (bio-)manipulation of South African reservoirs - viable eutrophication management prospect or illusory pipe dream? A reflective commentary and position paper
}

\author{
Rob C Hart \\ School of Biological and Conservation Sciences, University of KwaZulu-Natal, Pietermaritzburg 3201, South Africa
}

\begin{abstract}
An overview of prospects and limitations for the application of 'classical' top-down biomanipulation as a management tool to ameliorate the consequences of eutrophication under the conditions applicable to reservoirs in South Africa is presented. This is structured by considering successive stages in reservoir food-web structure and function as far as can be generalised for South African biophysical conditions. Features and conditions that influence the potential vulnerability of local reservoirs to the effects of eutrophication, and prospects for its amelioration by biomanipulation intervention are examined. Physical factors linked to latitude (irradiation pattern and water-column stability) enhance the potential severity of eutrophication consequences in local reservoirs, although conversely, these are offset by suspended-clay turbidity. The predominance of Microcystis in local eutrophic waters is perceived as a primary major constraint in implementing 'classical' food-web manipulation. Intrinsic limitations on the ability of zooplankton grazers to control this cyanobacterium, and subsequent food-web linkages widely applicable in local reservoirs are discussed and evaluated accordingly. On balance, available evidence indicates a range of limitations that are likely to apply in respect of familiar contemporary approaches to biomanipulation in use today, although the uniqueness of each reservoir ecosystem is recognised. Some novel alternative management approaches are suggested, and a range of associated research requirements necessary to advance locally relevant scientific comprehension of 'biomanipulation' and its application are itemised. National revitalisation of reservoir limnology remains paramount.
\end{abstract}

Keywords: eutrophication, management constraints and options, warm-water reservoirs, biomanipulation, research needs.

\section{Introduction}

Eutrophication - the enrichment of aquatic ecosystems by nitrogen and particularly phosphorus - is recognised as a serious and growing global threat to lakes, rivers and estuaries (OECD, 1982; Klapper, 1991; Moss, 1998; Straškraba and Tundisi, 1999; Holdren et al., 2001). The direct consequence of this nutrient 'pollution' is the excessive growth of autotrophic organisms in affected water-bodies. In standing waters, this manifests in blooms of generally undesirable planktonic 'algae' and/or prolific stands of rooted or floating vascular hydrophytes. The former commonly include 'harmful' toxic representatives, encapsulated as HABs (harmful algal blooms). (I use 'algae' as a collective term to include both conventional algae (photosynthetic eukaryote Protista), as well as photosynthetic prokaryote bacteria). Paradoxically, this elevated primary production is a major concern to the water quality of inland waters (OECD, 1982; Klapper, 1991; Moss, 1998; Straškraba and Tundisi, 1999; Holdren et al., 2001) in view of its profound and generally 'disruptive' impacts on ecosystem structure and functioning. Foremost amongst these are changes in the abundance and community structure of planktonic autotrophs, frequently resulting in nuisance 'algal' blooms. Planktonic eukaryote protistan algae (cryptophytes, dinoflagellates, chrysophytes and diatoms, green algae and euglenophytes) are commonly subjugated by prokaryotic blue-green algae - cyanobacteria, among whose members

mill +2733 260-5105; fax: +2733 260-5117;

e-mail: hartr@ukzn.ac.za

Received 19 April 2006; accepted in revised form 29 June 2006. toxic strains frequently arise, resulting in an array of subsequent changes in ecosystem functioning that are widely known today. The primary corrective measure for the control of eutrophication rests on reducing nutrient loading, principally through the integrated management of the drainage basin of the affected aquatic ecosystems. Globally, emphasis was initially directed at reducing nutrient loading rates (OEDC, 1982), an approach that was (e.g. Walmsley and Butty, 1980; Grobler and Silberbauer, 1984), and indeed remains prominent in the South African context (e.g. Walmsley, 2000; Anon., 2004a, b). However, progressive recognition of ecological-biotic interactions spawned partly from long-term studies of Lake Washington (Edmondson and Litt, 1982; Edmondson, 1994; Edmondson et al., 2003), and thereafter in a range of shallow lakes in several densely populated lowland nations in Europe (e.g. Gulati et al., 1990; Moss, 1999; Kairesalo and Vakkilainen, 2004) brought widespread recognition to Shapiro's (1980) now familiar concept of food web or biomanipulation - schematically illustrated in Fig. 1. This 'classical' or 'traditional' approach focuses on enhancing or suppressing particular linkages within the trophic cascade: primary producer $\rightarrow$ primary consumer $\rightarrow$ secondary consumer $\rightarrow$ tertiary consumer ('algae' $\rightarrow$ grazing zooplankters $\rightarrow$ zooplanktivorous fish $\rightarrow$ piscivorous fish) in any manner consistent with maximising the grazing pressure exerted on the autotrophs.

Biomanipulation has been widely applied in north temperate waters, with results varying from spectacular success (especially in 'shallow' lakes) to dismal failure (often in deep lakes) and a range of outcomes between these extremes (e.g. Gulati et al., 1990; De Bernardi and Giussani, 1995; Mehner et al., 2002; Benndorf et al., 2002). Perhaps partly from desperation at the severity of eutrophication evident in various South African 


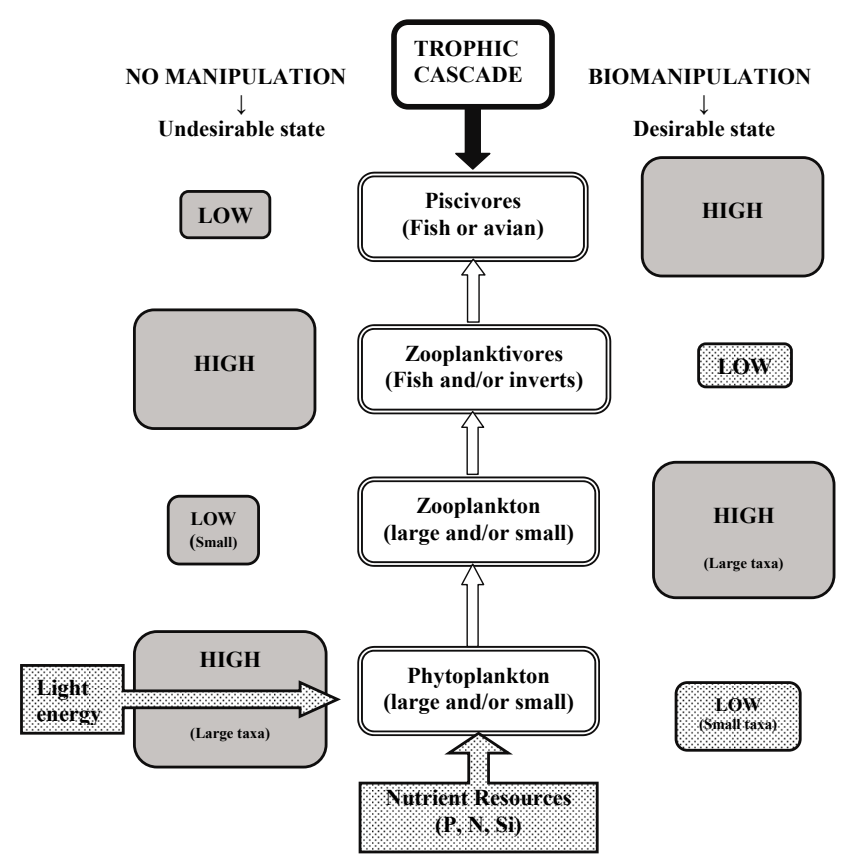

Figure 1

Simplified energy flow in pelagic ecosystems. 'Biomanipulation' attempts to reduce the pool size of alternate trophic levels by minimising or maximising drivers between relevant trophic couplings. Stippling indicates desirable reductions.

reservoirs, and a national inability to moderate or treat it, the overseas successes have prompted the recent proposal (Anon., 2004a) that biomanipulation or food-web interventions should be explored as a management tool for the growing problem manifesting in a (small) subset of reservoirs for which current data exist (van Ginkel, 2004a). 'As an isolated approach, the phosphate standard is a global failure. In many countries it is being pushed aside in favour of integrated treatment approaches with a strong biological component. European countries like Finland and the Netherlands have followed this route successfully for a number of years' (PJ Venter, cited in Anon., 2004a).

Despite its intrinsic appeal, Venter's progressive suggestion overlooks important ecological features of South African reservoirs that raise serious doubts about the practicality of food-web manipulation. Even overseas, its appeal is under scrutiny. Gulati and Van Donk (2002) accede that failures exceeded successes in The Netherlands, while experimental data compiled by Moss et al. (2004) demonstrate the increasing importance of bottomup nutrient controls as latitude declines - i.e. as waters become warmer, whereas top-down effects of fish predation remained comparable across latitudes (although this is recognised as a possible experimental artefact).

In this paper, I address selected issues of contextual relevance to eutrophication and its symptomatic expression under 'local' conditions; prospective limitations to biomanipulation that are already known from observational and experimental biological and ecological studies undertaken in South African reservoirs, or can be logically inferred from principals that have emerged from these studies and elsewhere, are considered. Having identified these potential limitations, I explore some possible solutions to reduce or obviate the constraints identified. A sequential bottom-up consideration of each of the successive steps (or 'trophic levels') in the feeding cascade is utilised as a template for this account. It must be stressed that no attempt is made to review the voluminous literature dealing with biomanipulation.
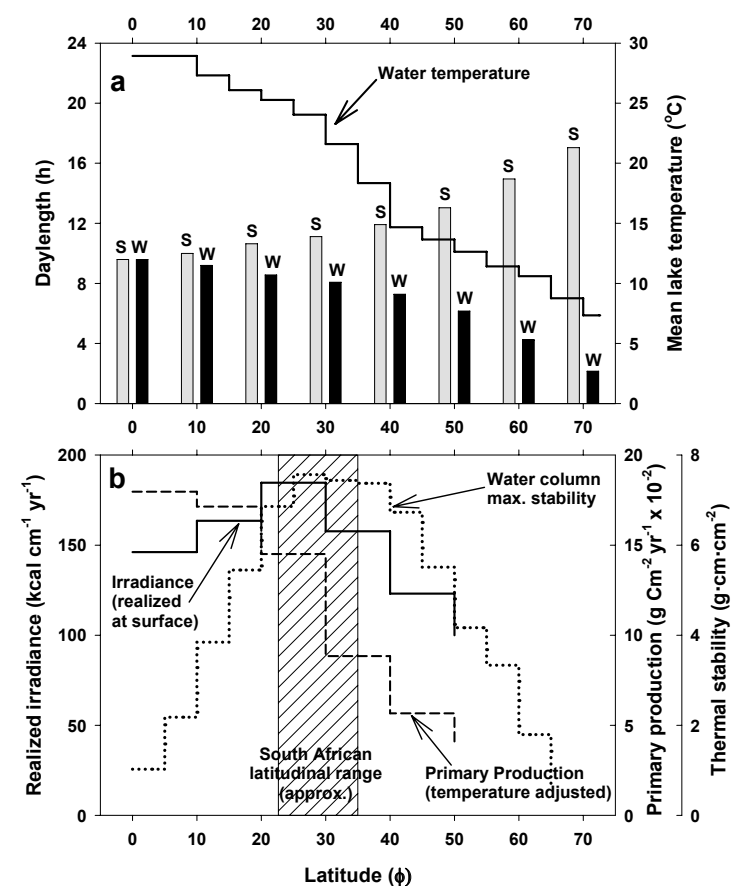

Figure 2

Latitude-related changes in various factors that affect eutrophication potential: a) Water temperature and daylength duration in summer (s) and winter (w). b) land-surface measured irradiance, temperature-adjusted primary production, and potential water column stability (After Straškraba (1980) and Lewis (1996)).

Rather, I simply identify local particularities or peculiarities of contextual relevance in biomanipulation prospects for South African standing waters. This augments accounts of the applicability and perceived limitations of classical biomanipulation in tropical waters (Arcifa and Northcote, 1997; Lazzaro, 1997).

\section{Primary producers - Composition and productivity constraints}

Information on phytoplankton structural composition in South African reservoirs is remarkably limited. Most studies have utilised chlorophyll content as a surrogate measure of 'algal' abundance, and have paid little attention to the population dynamics and specific composition of the phytoplankton assemblages. Nevertheless, the occurrence of cyanophytes - predominantly large colonial Microcystis - is an undeniable regional reality in eutrophic reservoirs (Harding and Paxton, 2001).

Although detailed systematic investigations of phytoplankton dynamics and periodicity are few (briefly elaborated by Hart, 2006), representative organisms indubitably experience a range of particular conditions (e.g. Davies and Walmsley, 1985; Hart and Allanson, 1984; Allanson et al., 1990; Lewis, 1996; Allanson, $1995 ; 2004)$ that have direct regional relevance to the phenomenon of eutrophication and the severity of its manifestation in South African (and perhaps more widely - Southern African) reservoirs. Foremost, these include high optical depth, temporally extended summer growing seasons without commensurately protracted day-length, and frequently, strong stratification intensity (Fig. 2). The intrinsic problem of high external nutrient loading to which reservoirs are invariably subjected as a consequence of their extreme hydraulic loading is taken as given. Management and control of this primary cause lies squarely in the realm of integrated catchment management, which lies outside the scope of this account (despite its primary importance). 


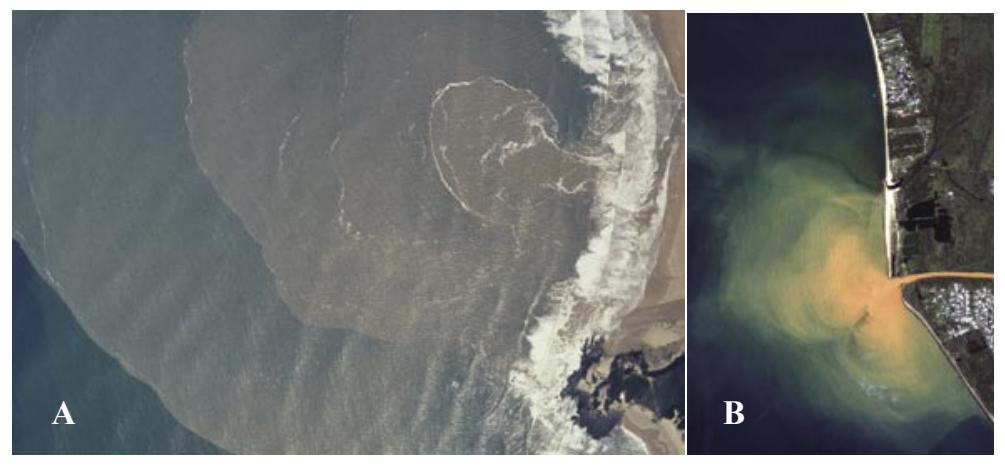

Figure 3

Marine discharge of sediment-laden plumes of (A) the Great Fish River (image courtesy of Dr AK Whitfield - South African Institute for Aquatic Biodiversity, Grahamstown) and (B) the Anasco River (image provided by the Geological and Environmental Remote Sensing Laboratory of the University of Puerto Rico at Mayagüez - Prof. F Gilbes-Santaella). The abrupt dissipation of the plume results partly from the coagulation and sedimentation of clay particles as a consequence of extreme changes in zeta potential associated with the transition from fresh to salt water.

- High optical depth, associated primarily with elevated suspended sediment content, is characteristic of most regional inland waters (Allanson et al., 1990), and imparts both positive and negative impacts in the context of reservoir eutrophication responses. On the positive side, light limitation imposed by suspended sediments serves as an important buffer to nutrient loading, thereby delaying the manifestation of eutrophication, as captured by Lind and Dávalos-Lind (1999): 'On balance, although the public often expresses the desire for clear blue water, the presence of suspended clays may be seen as beneficial - considering the generality of eutrophication and toxic contaminant threats.' Chlorophyllnutrient relationships are significantly weakened in comparison with clear-water systems, easily leading to a false sense of security regarding the problem of eutrophication. Conversely, however, increased zeta potential - the phenomenon of particle coagulation and sedimentation associated with salinisation - creates the prospect of an unusually rapid manifestation of the symptoms of eutrophication, either in drought years when 'normal' levels of anthropogenic salt inputs are not diluted as usual, or when any increase in salt loading arises. Despite early identification of this threat (Grobler et al., 1981) and its blatant manifestation where river plumes discharge to the sea (Fig. 3), its potential impact in freshwaters has been sorely disregarded.

The second adverse effect of high suspended sediment is the effective generation of an underwater light climate that favours cyanophytes like Microcystis. This arises from light-induced changes in colony size, buoyancy, and pigment content (Robarts and Zohary, 1984; Zohary and Robarts, 1989, 1990) that selectively favour this taxon. Significant blooms of Microcystis develop seasonally or episodically under certain hydrographic conditions even in waters that are otherwise characterised by strikingly low algal standing stocks, principally as a consequence of light limitation. One example is Lake le Roux (Fig. 4) where chlorophyll levels seldom exceed $5 \mu \mathrm{g} \cdot \ell^{-1}$ (e.g. Hart, 1986a). In the nutrientenriched but clay-turbid waters of Bridle Drift Dam on the Buffalo River, Microcystis surface scums thick enough to be traversed by large water monitor lizards (Varanus niloticus) have been observed (Selkirk, 2002). The competitive advantage of the physically large Microcystis is further enhanced by its relative immunity to grazing zooplankters (as elaborated below).

- An extended growing season ('continuous summer'), with commensurately extended and often strong stratification (as summarised schematically in Fig. 2) offers both opportunities and constraints to planktonic algae. Day-length and its annual variability, along with elevated temperatures (Fig. 2a) confer synergistic beneficial effects on primary production. Since these physical attributes also largely determine water column stability (Fig. 2b), they further potentially influence subsequent hypolimnetic nutrient sequestration. Contextually, their relevance to planktonic primary production and

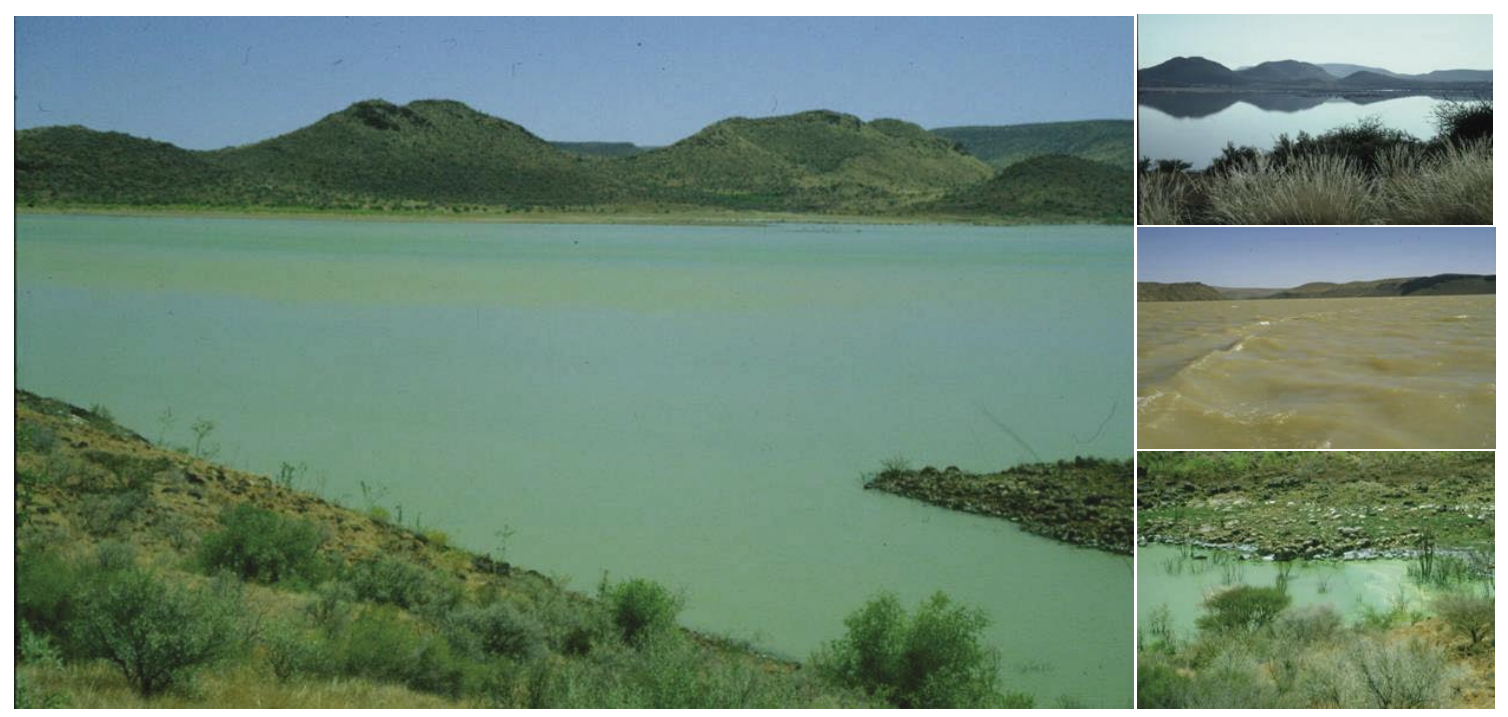

Figure 4

Significant blooms of the cyanophyte Microcystis arise in the otherwise turbid light-limited waters of Lake le Roux, under particular hydrographic conditions (Photos: RC Hart). 
the symptomatic manifestation of eutrophication is indubitable. Although winter growth inhibition by short, low light intensity day-length is effectively limited, prospects of extended nutrient deficiency are conversely suggested by the longer and potentially stronger thermal stratification. Summer is certainly not 'endless' (Kilham and Kilham, 1990), but it is definitely protracted. Prolonged nutrient sequestration associated with this extended stratification clearly favours $S$-selected algae - among which cyanophytes are prominent (Reynolds, 1996). Problematic cyanophyte taxa like Microcystis that are able to maximise growth by cyclically exploiting deep-water nutrient stores as well as light in surface waters through their vertical 'migration', are greatly favoured (Reynolds, 1999), as is well known from extensive works on Hartbeespoort Dam (e.g. Robarts and Zohary, 1984; Zohary and Robarts, 1989; 1990.)

South African reservoirs obviously vary widely in depth, and wind-exposure, affecting the prospect, intensity and duration of thermal stratification. Generally, however, major reservoirs are relatively deep. Among 110 reservoirs with a full supply capacity exceeding $2.5 \times 10^{6} \mathrm{~m}^{3}$ in the Department of Water Affairs (1986) inventory, median and average mean depths were respectively $10.2 \mathrm{~m}$ and $11.9 \mathrm{~m}$, reflecting their corresponding vulnerability to stratification.

- Day-length limitation serves as a potential foil to offset the extended growing season considered above. At the latitudes involved, day-length is seldom longer than $14 \mathrm{~h}$, in contrast to summer day-lengths theoretically of up to $18 \mathrm{~h}$ experienced at higher cold temperate latitudes (Fig. 2a). Conversely, however, duration (and intensity) of sunlight exposure is potentially offset by overcast conditions associated with extended cloud cover commonly experienced in these higher latitudes.

Alternative prospects: Although not 'classical' biomanipulation, and despite the fact that documented regional case studies on phytoplankton succession are severely limited, it can be inferred from first principles that the re-direction of succession (for example, by artificial de-stratification) may offer a potential mechanism to prevent or reduce the predominance of Microcystis during summer stratification. Any induced switch away from this (and other) large autotrophs can be anticipated to improve prospective reduction or control of problem algae by grazing zooplankters.

\section{Grazing zooplankters - Composition and food selection}

Mechanistically, biomanipulation rests on the presumed ability of grazing zooplankters to regulate algal growth (Fig. 1). Such regulation hinges strongly on the impact of large-bodied zooplankters - especially large daphniids that exhibit disproportionately high grazing rates, as originally perceived by Hrbáček (1962), and embraced as the 'Size Efficiency Hypothesis' by Brooks and Dodson (1964), although this keystone feature of the biomanipulation concept was definitively validated experimentally only as recently as 1990 (Gliwicz, 1990a).

Early recognition of food-size limitations in Daphnia's feeding ability derived from experimental feeding exposures using size-fractionated Microcystis from the notoriously hypertrophic Hartbeespoort Dam (Jarvis et al., 1987; 1988). Parallel demonstrations of the disruptive influences of filamentous algae on Daphnia feeding and hence fitness (Gliwicz, 1990b; Gliwicz and Lampert, 1990) followed subsequently. Under South
African conditions where Microcystis appears so prominent (Harding and Paxton, 2001), this knowledge logically counters prospects for useful application of biomanipulation in 'clearwater' systems.

It is also further known that daphniid cladocerans are widely constrained by high mineral turbidity (Hart, 1988; 1992); daphniids are seldom numerically prominent in reservoirs like Vanderkloof Dam - formerly Lake le Roux (Hart, 1986a) and Spioenkop Dam (Hart, 1999) where mineral turbidity is high. This general pattern is mechanistically explicable - and is directly attributable to a fundamental attribute of their feeding biology (e.g. Hart, 1988; Kirk, 1991; Levine et al., 2005). As daphniid cladocerans are intrinsically indiscriminate filterfeeders on small particles (Geller and Müller, 1981) within the wide size range of natural seston, their acquisition of nutritional particles is effectively overwhelmed by their parallel collection of suspended sediment, and the subsequent rejection of the resulting 'food' bolus. Prospects of 'classical' biomanipulation are accordingly constrained by intrinsic attributes of daphniid feeding biology - both in reservoirs with high mineral turbidity as well as in eutrophic systems where high biogenic turbidity is associated with large cyanobacteria. While diaptomid calanoid copepods commonly replace daphniids as the dominant largebodied zooplankton component in turbid reservoirs (e.g. Hart, 1991), their significantly lower maximal feeding rates and Incipient Limiting Levels (Muck and Lampert, 1984) greatly reduce their potential impact as algal grazers. Furthermore, their selective raptorial feeding allows them to target good quality food items almost exclusively - they thereby avoid the undesirable cyanophytes associated with eutrophication.

Within the limited observational data set available for warmwater reservoirs, the prospective role of zooplankton grazing as a top-down control mechanism for phytoplankton is contradictory; low average community grazing rates $\left(<10 \% \cdot \mathrm{d}^{-1}\right)$ in the minerally turbid waters of Lake le Roux (Hart, 1984; 1986b) contrast with much higher values $\left(>75 \% \cdot \mathrm{d}^{-1}\right)$ in the hypertrophic Hartbeespoort Dam (Jarvis, 1986). But even two very comparable neighbouring reservoirs in a single cascade exhibit strikingly different relationships between phytoplankton and zooplankton biomass; some evidence of grazer control of algae in the downstream Albert Falls Dam system contrasts with an apparent algal-grazer independence in the upstream Midmar system (Fig. 5). It is worth noting that the predominant autotroph in Midmar during periods of elevated phytoplankton standing stock was commonly Aulacoseira (Hart, 2006), a large filamentous species that is barely consumed by Daphnia, but is ingested (rather like spaghetti) by calanoid copepods (Hart, 1987). Such system-specific and sometimes subtle differences emphasise the necessity for fundamental basic investigations before biomanipulation (and other interventions) are seriously contemplated.

Other prospects: The constraints on direct herbivory by grazing zooplankters considered above suggest that alternative mechanisms of phytoplankton consumption or mortality should be explored. The most obvious option in this regard rests on enhancement of the detritus food chain/microbial loop. Sustained high temperatures obviously stimulate microbial activity. As it senesces, Microcystis becomes 'over-buoyant' and accumulates as a decomposing hyperscum beneath a photo-oxidised surface crust (Zohary and Robarts, 1990) to provide an organic source for heterotrophic microbial degradation. While the food-web dynamics associated with this degradation are poorly known, a major role of cyclopoid copepods is suggested by their frequent predominance under such conditions. Quantitative determina- 


\section{Figure 5}

Contrasting biomass interrelationships between primary producers (as chlorophyll content) and primary consumers (as Daphnia standing stock) in neighbouring reservoirs on the uMngeni River, KwaZulu-Natal
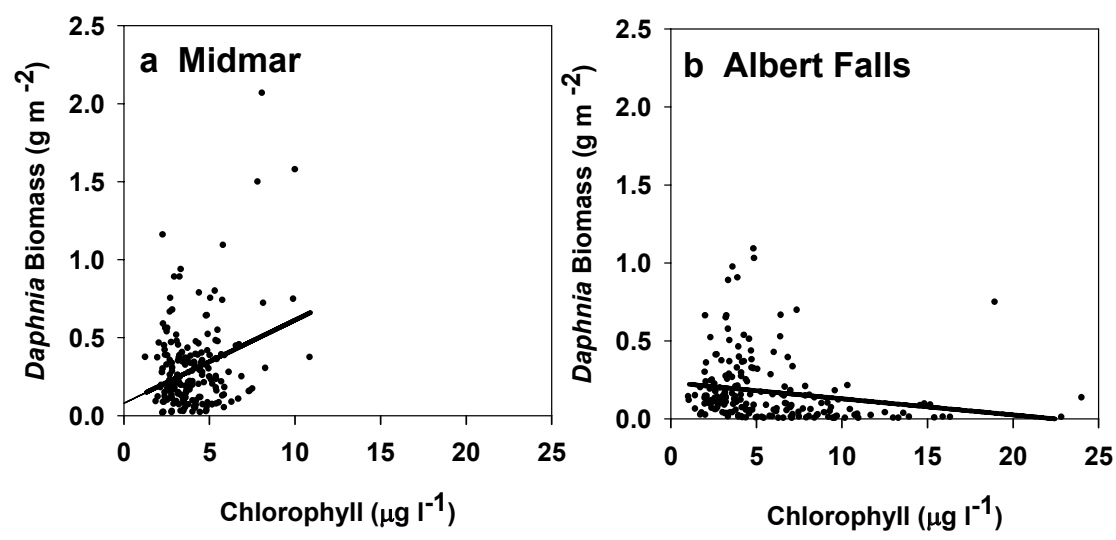

tions of the role of cyclopoid copepods as potential consumers of microzooplankton, and of the consumptive role of the microzooplankton itself (ciliates, flagellates, rotifers, etc.) to provide an integrated assessment of the microbial and macrobial loops in eutrophic waters may expose opportunities to enhance consumptive losses of large autotrophs like Microcystis.

The challenge is to somehow reduce the unidirectional constraints of 'donor-control' in this detritivore pathway that contrasts fundamentally with the direct interactive feedback between consumer and food resource that pertains in pathways of functional predation (Begon et al., 1996). Where practically feasible, the confinement of Microcystis scums and hyperscums by a floating 'curtain' could accelerate the decomposition of living colonies, and thereby sustain the provision of dead organic matter to fuel and maintain the resultant microbial loop. (Conversely, as the population dynamics of Microcystis are closely tied to mixing depth (Zohary and Robarts, 1989), turbulence created by artificial circulation can accordingly be used to prevent this buoyant cyanobacterium from assuming dominance).

Finally, although the underlying mechanisms remain unclear, the collapse of cyanobacterial blooms as a consequence of viral lyses has been shown to be very effective (Brussaard, 2004; Simis et al., 2005), suggesting that virally-induced mortality of Microcystis could be similarly manipulated as a corrective measure against this consequence of eutrophication. Such viral lysis would concomitantly short-circuit the microbial loop (Wommack and Colwell, 2000), directing carbon and nutrients into potentially less undesirable biota.

\section{Zooplanktivores}

As artificial systems, river reservoirs in South Africa do not contain indigenous, obligate zooplanktivorous fishes. Unlike the situation that pertains generally in natural lakes, reservoir zooplankton is accordingly not exposed to predation by a specialist feeding guild of fishes. Predation by fish is instead restricted to that associated with opportunistically facultative zooplanktivores. These largely comprise juveniles of a predominantly or exclusively 'littoral' assemblage of river-derived cichlids (especially in warmer localities), and some species of yellowfish (Barbus), and the catfish (Clarias gariepinus) that move into open 'offshore' waters. While the former two groups will largely function as typical sizeselective, visual predators when they do feed on zooplankton, Clarias more plausibly functions as a size-independent gulp-feeding bulk consumer when it utilises zooplankton. However, the prospective role of Clarias as a zooplanktivore remains uncertain.
Numerically, young cichlids are likely to be the predominant (facultative) zooplanktivore in reservoirs. However, their impact as planktivores is anticipated to be largely constrained, both spatially and temporally. The riverine origin or derivation of this cichlid assemblage imposes a relatively strong footprint - confining them largely to littoral margin inshore habitats to avoid piscivorous birds and/or fish. Accordingly, their predatory impact on zooplankton in offshore open-water reaches of the reservoirs they inhabit is presumed to be correspondingly limited. As a group, cichlids are principally summer-breeders, imposing a correspondingly limited temporal occurrence of the more voracious smaller young of year (YOY) individuals. Largest numbers of YOY fish are likely to broadly coincide temporally with the seasonal emergence or switch to dominance of undesirable summer cyanophytes. This timing of their potential impact as zooplanktivores is seasonally least desirable, in relaxing the grazing pressure on phytoplankton at a critical stage - when Microcystis colonies in particular may still be small enough to be grazed by Daphnia (Jarvis et al., 1987). While there is little empirical evidence to suggest that tilapiine cichlids play a major negative top-down role in the context of reservoir eutrophication, presumably largely because of their 'littoral' restriction, the indigenous cichlid Chetia flaviventris that has proliferated in Hartbeespoort Dam is perceived (Anon., 2004b) to be a significant zooplanktivore. In contrast to top-down effects, the bottomup influences of cichlids may be very significant, as documented by Starling et al. (2002). Since bottom-up effects of nutrient availability appear to increase with declining latitude (Moss et al., 2004), the role of these cichlids may lie primarily in nutrient regeneration rather than top-down predatory influences.

Facultative zooplanktivores such as the small-mouthed yellowfish Barbus aeneus can exert a stronger top-down control as documented for Lake le Roux, where zooplankton biomass and fish catch correlated directly (Hart, 1986a), despite constraints on visual zooplanktivory imposed by high levels of mineral turbidity. The invariably sharp limitation in vertical distribution of Barbus aeneus in gill-net catches in this lake (Fig. 6) is entirely consistent with visual constraints on their foraging behaviour. Continued co-existence of large-bodied zooplankton taxa ( $L o v-$ enula and Daphnia gibba) with visual predators (Hart, 1986a) is further consistent with the visual refuge from predation afforded by suspended sediments.

In strong contrast to a largely indiscernible impact of native fishes, exotic species like the pelagic sardine Limnothrissa miodon introduced into Lake Kariba has greatly depressed the size structure, lowered abundance levels, and affected vertical depth distribution of zooplankton in Kariba (Marshall, 1997). Superficially at least, classical biomanipulation remains a prospective management option here, should eutrophication impact this major reservoir. 

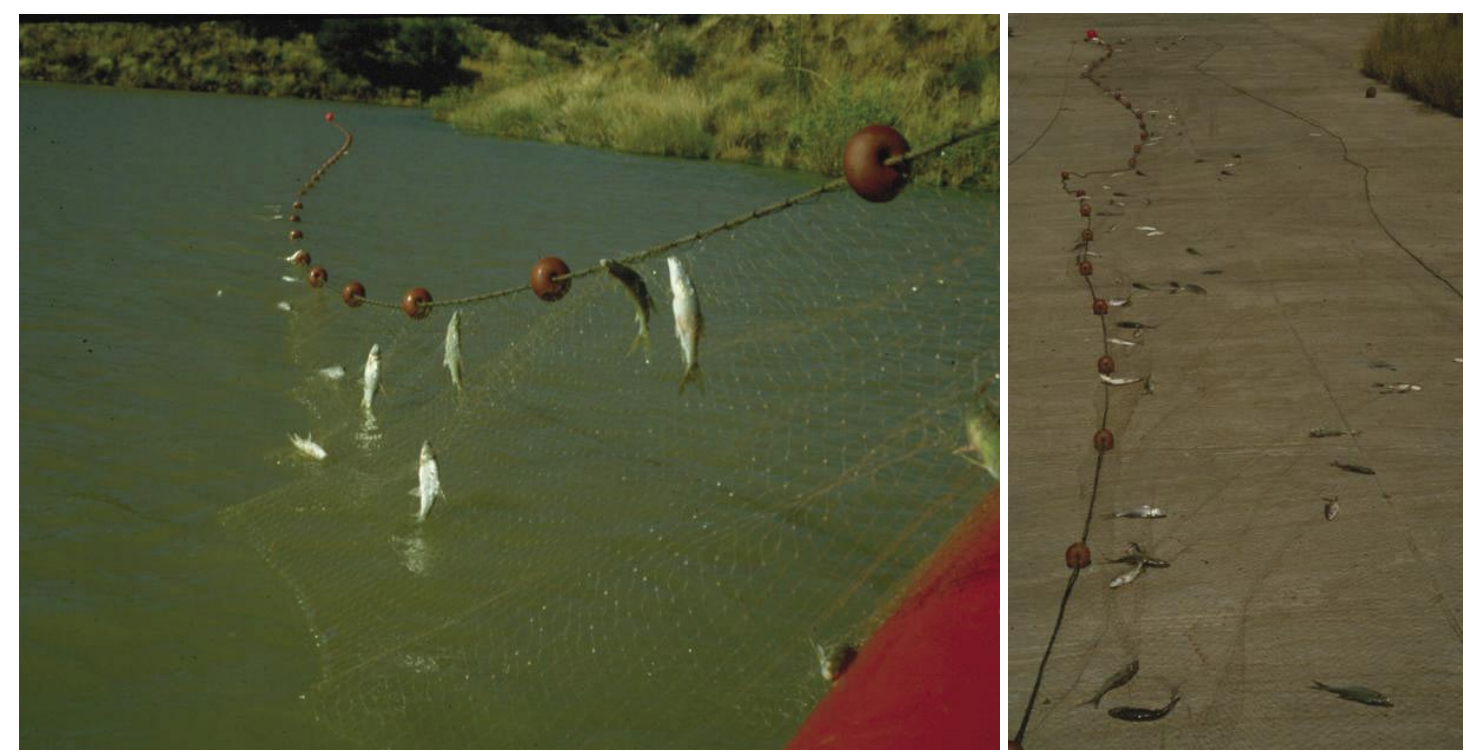

Figure 6

Near-surface restriction of the facultative zooplanktivore Barbus aeneus reflected in gill-net catches in the clay-turbid waters of Lake le Roux (Orange River) (Photos: RC Hart)

While relatively large invertebrate zooplanktivores such as Mysis and Leptodora do not occur in South African reservoirs, Chaoborus exists as an almost ubiquitous component of the zooplankton assemblage. Its selective impact as a tactile predator on small-bodied species or stages is directionally consistent with the underlying principle of classical biomanipulation - the enhancement of large-bodied 'herbivorous' zooplankton; its presence may be correspondingly beneficial.

Alternative prospects: As Lazzaro (1997) comments, the impact of invertebrate zooplanktivores in tropical waters is poorly known. From first principles, however, the enhancement of tactile predation to favour large- rather than small-bodied 'herbivorous' zooplankton seems plausible. The widespread existence of Chaoborus in local reservoirs noted above would appear propitiously appropriate in this context, although Lazzaro (1997) conversely envisages Chaoborus predation as limiting (rather than augmenting) the abundance of large zooplankton - presumably through size-selective predation on their small or juvenile instars. Partly countering the latter, however, an extensive literature attests to the demographic feedback that exists - in the socalled 'maternal' effect reported for Daphnia (Lampert, 1993; Tollrian, 1995). Basic, integrated holistic consideration and elucidation of 'cascade' effects, indirect linkages and trophic feed-backs remain essential if any of the prospects contemplated above are to be pursued rationally.

Additional complexity may be associated with non-indigenous taxa such as carp (Cyprinus spp.) and blue-gill sunfish Lepomis macrochirus that are widely distributed in suitable reservoirs. Their potential role in zooplanktivory also requires evaluation.

\section{Piscivores}

Enhancing piscivore abundance to increase top predator impacts on planktivorous fishes has been a common treatment practice in biomanipulation attempts (e.g. Gulati et al., 1990). In the context of local reservoirs, however, this is arguably superfluous or redundant, since as discussed above, zooplanktivory is intrinsically low owing to the fish community structure, leaving
Daphnia largely unscathed. Despite limited fish predation, the ability of these large-bodied grazers to control algae is otherwise compromised by the large size and associated inedibility and/or un-palatability of Microcystis.

However, the impact of avian piscivores (especially cormorants) on reservoir food webs merits examination. These are likely to serve as important predators of zooplanktivorous fish, and especially YOY cichlids. By confining the latter to inshore regions, at least during daylight, they may be expected to enhance the top-down control of planktonic autotrophs by zooplankton grazers.

Exotic fish species such as largemouth bass (Micropterus salmoides) have been widely introduced as game-fish in reservoirs. This is a major fisheries species in Albert Falls - precisely where an inverse zooplankton-chlorophyll relationship (Fig. 5b) consistent with top-down control associated with biomanipulation was observed. While this piscivore also occurs in Midmar, the impact of its smaller population in this upstream reservoir may be further reduced or countered by prolonged or greater clay turbidity, or both, thereby indirectly contributing to the seeming lack of evidence for zooplankton control of algal biomass (Fig. 5a).

Alternative prospects: In the absence of strong zooplanktivory by fish, enhancing piscivorous fish would appear largely redundant. However, enhancing avian piscivores would prospectively strengthen existing top-down impacts of grazing zooplankters. Again, it is worth noting that Albert Falls, where the classical biomanipulation outcome is evidenced in Fig. 5b, supports a large breeding colony of darters (Anhinga melanogaster) and white-breasted cormorants (Phalacrocorax carbo), at least during low-water years (Fig. 7). Information regarding the precise local diet and foraging patterns of these breeding birds is not available. Although they may acquire more or most food from neighbouring water-bodies - small farm dams and streams - they certainly do feed in Albert Falls (Hart, pers. obs.).

\section{Summary and research needs}

As far as can be generalised, prospects for applying "classical' biomanipulation as a management tool to ameliorate con- 
Figure 7

Nesting Darters (Anhinga melanogaster) constitute a small isolated section of a large breeding colony of piscivorous birds on Albert Falls (Photo: RC Hart)

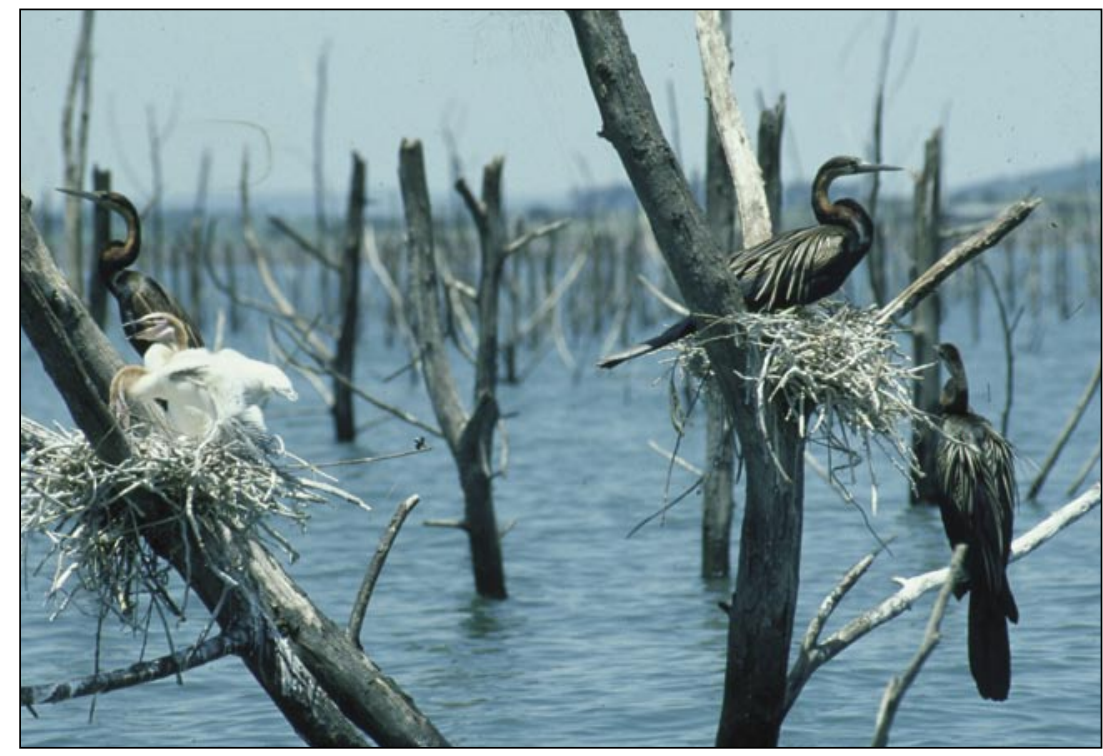

sequences of eutrophication in local reservoirs are weak. The foregoing account serially elucidates particular circumstances prevailing in many reservoir systems that serve to reduce such prospects. These constraints arise from fundamental and virtually inviolate basic features of the biota involved in the organic productivity of these reservoirs and their associated food-web structure and functioning. Several alternative or additional approaches to 'classical' biomanipulation in the local context that merit examination have been suggested as possibilities in the foregoing account. Fundamentally, however, their exploration requires a committed significant regional revitalisation of reservoir limnology (Hart and Hart, 2006) if such prospects are to be founded on practical and objective comprehension. In the context of eutrophication management, a number of outstanding general questions and issues regarding reservoir structure and function have been identified. Re-iterated at a rather superficial level, these include:

- The analysis, synthesis and identification of patterns and trends in phytoplankton dynamics in reservoirs. Once 'defined', prospects to manage the associated problems will be greatly improved. Large relevant data sets collected by state and parastatal water agencies (DWAF, various regional Water Boards) and local authorities (metropolitan municipal services) are understood to exist, but remain largely uninterrogated.

- An initiation of fundamental studies on microbial loop dynamics and their impacts on nutrient recycling and energy flow in representative reservoirs affected by eutrophication. What prospects exist to enhance the microbial decomposition of HAB's? What trophic roles does microzooplankton - ciliates, flagellates and rotifers - serve in the food-webs of local reservoirs? Can these microbial food-webs be manipulated in any manner commensurate with the objectives of food-web manipulation? What associated water quality problems (apart from or in addition to inevitably greater deoxygenation of deep-water layers) are likely to arise in consequence thereof? Can these be mitigated to any meaningful degree? How?

- Elucidation of the nature and role of cyclopoid copepod feeding and its influence on energy and nutrient flow in eutrophic warm-water reservoirs. Zooplankton of Roodeplaat Dam (Van Ginkel, 2004b) and Inanda Dam (Hart, pers. obs.) are seemingly dominated by cyclopoid copepods, the trophic guilds of which have not received even cursory examination. Their role in microbial loop dynamics in local reservoirs remains purely inferential.

- Consideration of the size-selective predatory impact of Chaoborus. Can this be effectively utilised to enhance the predominance of large-bodied zooplankton grazers that are known to exert disproportionately strong control on phytoplankton?

- Characterisation and quantification of the role and impacts of indigenous haplochromine and tilapiine cichlids (YOY and later life stages) and catfish as zooplanktivores in local reservoirs. How strongly are these restricted to near-shore regions? How 'seasonal' is their influence? Can their impact be selectively reduced by fish and/or avian piscivores?

- Analysis of the impacts of exotic fish species (carp, sunfish and bass) as potential zooplanktivores and/or piscivores. Can exotic fishes (as well as complete assemblages of indigenous and exotic taxa) be selectively manipulated to enhance top-down influences and reduce the consequences of eutrophication?

\section{References}

ALLANSON BR (1995) An Introduction to the Management of Inland Water Ecosystems in South Africa. WRC Report No TT 72/95. Water Research Commission, Pretoria, South Africa. 77 pp.

ALLANSON BR (2004) Limnology in South Africa: Past and present status and future needs. In: Gopal B and Wetzel RG (eds.) Limnology in Developing Countries (Vol 4). International Association for Theoretical and Applied Limnology. International Scientific Publications, New Delhi, India. 1-116.

ALLANSON BR, HART RC, O'KEEFFE JH and ROBARTS RD (1990) Inland Waters of Southern Africa: An Ecological Perspective. Kluwer Academic Publishers, Dordrecht. 458 pp.

ANON (2004a) New hope for troubled waters: The Hartbeespoort Dam test case. The Water Wheel 3 (1) 16-19.

ANON (2004b) Hartbeespoort Dam: An action plan. The Water Wheel 3 (6) 6-10.

ARCIFA MS and NORTHCOTE TG (1997) Need for holistic approaches in food web experiments and biomanipulation in tropical lakes: A Brazilian reservoir experience. Verh. Int. Ver. Limnol. 26 661-665.

BEGON M, HARPER JL and TOWNSEND CR (1996) Ecology: Individuals, Populations and Communities ( $3^{\text {rd }}$ edn.). Blackwell Scientific, Oxford. $1068 \mathrm{pp}$. 
BENNDORF J, KNESCHKE H, KOSSATZ U and PENTZ E (1984) Manipulation of the pelagic feed web by stocking with predacious fish. Int. Rev. Hydrobiol. 69 407-428.

BENNDORF J, BÖING W, KOOP J and NEUBAUER I (2002) Topdown control of phytoplankton: the role of time scale, lake depth and trophic state. Freshwater Biol. 47 2282-2295.

BROOKS JL and DODSON SI (1965) Predation, body size, and composition of plankton. Sci. 150 28-35.

BRUSSAARD CPD (2004) Viral control of phytoplankton populations - A review. J. Eukaryot. Microbiol. 51 125-138.

DAVIES BR and WALMSLEY RD (1985a) Perspectives in Southern Hemisphere Limnology: Introduction. Hydrobiol. 125 1-5.

DAVIES BR and WALMSLEY RD (eds.) (1985b) Perspectives in Southern Hemisphere Limnology. Developments in Hydrobiology (Vol 28). Dr W Junk Publishers, Dordrecht. 263 pp.

DE BERNARDI R and GIUSSANI G (eds.) (1995) Biomanipulation in Lakes and Reservoirs Management: Guidelines of Lake Management (Vol 7). ILEC/UNEP, Kusatsu, Shiga, Japan. 215 pp.

DEPARTMENT OF WATER AFFAIRS (1986) Management of the Water Resources of the Republic of South Africa. Department of Water Affairs, Pretoria. $457 \mathrm{pp}$

DUNCAN A (1997) Quantifying the fish-zooplankton interaction as an ecosystem response. A historical account of the $16^{\text {th }}$ PEG meeting 1984. Archiv. Hydrobiol. Beih. Ergebn. Limnol. 49 139-152.

EDMONDSON WT (1994) Sixty years of Lake Washington: A curriculum vitae. Lake and Reservoir Manage. 10 75-84.

EDMONDSON WT, ABELLA SEB and LEHMAN JT (2003) Phytoplankton in Lake Washington: Long-term changes 1950-1999. Archiv. für Hydrobiol. Suppl. 139 275-326.

EDMONDSON WT and LITT AH (1982) Daphnia in Lake Washington. Limnol. Oceanogr. 27 272-293.

GELLER W and MÜLLER H (1981) The filtration apparatus of Cladocera: filter mesh-sizes and their implications on food selectivity. Oecologia 49 316-321.

GLIWICZ ZM (1990a) Food thresholds and body size in cladocerans. Nature 343 (6259) 638-640.

GLIWICZ ZM (1990b) Why do cladocerans fail to control algal blooms? Hydrobiol. 200/201 83-97.

GLIWICZ ZM (1990c) Daphnia growth at different concentrations of blue-green filaments. Archiv. für Hydrobiol. 120 51-65.

GLIWICZ ZM and LAMPERT W (1990) Food thresholds in Daphnia species in the absence and presence of blue-green filaments. Ecol. 71 691-702.

GLIWICZ ZM (2002) On the different nature of top-down and bottomup effects in pelagic food webs. Freshwater Biol. 47 2296-2312.

GROBLER DC, DAVIES E and YOUNG L (1981) The stability of sediment/water suspensions as a function of water chemistry. In: Hattingh WHJ (ed.) Water year +10 and then? Dept of Water Affairs, Forestry and Environmental Conservation. Technical Report 114 $33-46$.

GULATI RD and VAN DONK E (2002) Lakes in the Netherlands, their origin, eutrophication and restoration: State-of-the-art review. Hydrobiol. 478 73-106.

GULATI RD, LAMMENS EHRR, MEIJER M-L and VAN DONK E (eds.) (1990) Biomanipulation - Tool for Water Management. Kluwer Academic Publishers, Dordrecht, Belgium. 628 pp.

HARDING WR and PAXTON BR (2001) Cyanobacteria in South Africa: A Review. WRC Report No TT/153/01. Water Research Commission, Pretoria, South Africa. 165 pp.

HART RC (1984) Zooplankton community grazing in silt-laden Lake le Roux, Orange River, South Africa. Verh. Int. Ver. Limnol. 22 $1602-1607$

HART RC (1986a) Zooplankton abundance, community structure and dynamics in relation to inorganic turbidity, and their implications for a potential fishery in subtropical Lake le Roux, South Africa. Freshwater Biol. 16 351-371.

HART RC (1986b) Aspects of the feeding ecology of turbid water zooplankton. In situ studies of community filtration rates in silt-laden Lake le Roux, Orange River, South Africa. J. Plankton Res. 8 401-426.

HART RC (1987) Observations on calanoid diet, seston, phytoplankton-zooplankton relationships, and inferences on calanoid food limitation in a silt laden reservoir. Archiv. für Hydrobiol. 111 67-82.
HART RC (1988) Zooplankton feeding rates in relation to suspended sediment content: potential influences on community structure in a turbid reservoir. Freshwater Biol. 19 123-139.

HART RC (1991) Food and suspended sediment influences on the naupliar and copepodid durations of freshwater copepods: Comparative studies on Tropodiaptomus and Metadiaptomus. J. Plankton Res. 13 645-660.

HART RC (1992) Experimental studies on food and suspended sediment effects on growth and reproduction of six planktonic cladocerans. J. Plankton Res. 14 1425-1448.

HART RC (1999) On the limnology of Spioenkop, a turbid reservoir on the upper Thukela River, with particular reference to the structure and dynamics of its plankton community. Water SA 25 519-527.

HART RC (2006) Phytoplankton dynamics and periodicity in two cascading warm-water reservoirs from 1989 to 1997 - taxonomic and functional (C-S-R) patterns, and determining factors. Water $S A \mathbf{3 2}$ (1) $81-92$.

HART RC and ALLANSON BR (eds.) (1984) Limnological Criteria for Management of Water Quality in the Southern Hemisphere. South African National Scientific Programmes Report No 93. FRD, CSIR, Pretoria. $181 \mathrm{pp}$.

HART R and HART RC (2006) Reservoirs and their Management: A Review of the Literature since 1990. WRC Report No KV 173/06. Water Research Commission, Pretoria, South Africa. 300 pp.

HOLDREN CW, JONES W and TAGGART J (2001) Managing Lakes and Reservoirs ( $3^{\text {rd }}$ edn.). North American Lake Management Society and Terrene Institute, in cooperation with Office of Water, Assessment and Watershed Protection Division - US Environmental Protection Agency, Madison, WI. xiv + 382 pp.

HRBACEK J (1962) Species composition and the amount of zooplankton in relation to the fish stock. Rozpr. Csav. Rad. Mat. Prir. Ved. 72 1-114.

JARVIS AC (1986) Zooplankton community grazing in a hypertrophic lake (Hartbeespoort Dam, South Africa). J. Plankton Res. 8 1065-1078.

JARVIS AC, RC HART and COMBRINK S (1987) Zooplankton feeding on size fractionated Microcystis colonies and Chlorella in a hypertrophic lake (Hartbeespoort Dam, South Africa): Implications to resource utilization and zooplankton succession. J. Plankton Res. 9 1231-1249.

JARVIS AC, HART RC and COMBRINK S (1988) Cladoceran filtration rate-body length relations: model improvements developed for a Microcystis dominated hypertrophic reservoir. J. Plankton Res. 10 115-131.

KAIRESALO T and VAKKILAINEN K (2004) Lake Vesijärvi and the city of Lahti (southern Finland): Comprehensive interactions between the lake and the coupled human community. SIL News 41 $1-5$

KILHAM P and KILHAM SS (1990) Endless summer - internal loading processes dominate nutrient cycling in tropical lakes. Freshwater Biol. 23 379-389.

KIRK KL (1991) Suspended clay reduces Daphnia feeding rate: Behavioral mechanisms. Freshwater Biol. 25 357-365.

KLAPPER H (1991) Control of Eutrophication in Inland Waters. Ellis Horwood Series in Water and Wastewater Technology. 337 pp.

LAMPERT W (1983) Biomanipulation - eine neue Chance zur Seesanierung? Biologie in unserer Zeit. 13 79-86.

LAMPERT W (1993) Phenotypic plasticity of the size at first reproduction in Daphnia: the importance of maternal size. Ecol. 741455 1466.

LAZZARO X (1997) Do the trophic cascade hypothesis and classical biomanipulation approaches apply to tropical lakes and reservoirs? Verh. Int. Ver. Limnol. 26 719-730.

LEVINE SN, ZEHRER RF and BURNS CW (2005) Impact of resuspended sediment on zooplankton feeding in Lake Waihola, New Zealand. Freshwater Biol. 50 1515-1536.

LEWIS WM Jr (1996) Tropical lakes: How latitude makes a difference. In: Schiemer F and Boland KT (eds.) Perspectives in Tropical Limnology. SPB Academic Publishing bv, Amsterdam, The Netherlands. 43-64.

LIND OT and DÁVALOS-LIND L (1999) Suspended clay: Its role in reservoir productivity. In: Tundisi JG and Straškraba M (eds.) 
Theoretical Reservoir Ecology and its Application. Backhuys, Leiden. pp 85-97.

MARSHALL BE (1997) A review of zooplankton ecology in Lake Kariba. In: Moreau J (ed.) Advances in the Ecology of Lake Kariba. University of Zimbabwe Publications, Harare. 102-119.

MEHNER T, BENNDORF J, KASPRZAK P and KOSCHEL R (2002) Biomanipulation of lake ecosystems: Successful applications and expanding complexity in the underlying science. Freshwater Biol. 47 2453-2465.

MOSS B, STEPHEN D, BALAYLA DM, BÉCARES E, COLLINGS SE, FERNÁNDEZ-ALÁEZ C, FERNÁNDEZ-ALÁEZ M, FERRIOL C, GARCÍA P, GOMÁ J, GYLLSTRÖM M, HANSSON L-A, HIETALA J, KAIRESALO T, MIRACLE MR, ROMO S, RUEDA J, RUSSELL V, STÅHL-DELBANCO A, SVENSSON M, VAKKILAINEN K, VALENTÍN M, VAN DE BUND WJ, VAN DONK E, VINCENTE E and VILLENA MJ (2004) Continental-scale patterns of nutrient and fish effects on shallow lakes: synthesis of a panEuropean mesocosm experiment. Freshwater Biol. 49 1633-1649.

MUCK P and LAMPERT W (1984) An experimental study on the importance of food conditions for the relative abundance of calanoid copepods and cladocerans. 1. Comparative feeding studies with Eudiaptomus gracilis and Daphnia longispina. Archiv. für Hydrobiol. 66 157-179.

ORGANISATION FOR ECONOMIC CO-OPERATION AND DEVELOPMENT (1982) Eutrophication of Waters. Monitoring, Assessment and Control. OECD Publications. $154 \mathrm{pp}$.

REYNOLDS CS (1996) Plant life of the pelagic. Verh. Int. Ver. Limnol. 26 97-113.

REYNOLDS CS (1999) Phytoplankton assemblages in reservoirs. In: Tundisi JG and Straškraba M (eds.) Theoretical Reservoir Ecology and its Application. Backhuys, Leiden. 439-456.

REYNOLDS CS, HUSZAR V, KRUK C, NASELLI-FLORES L and MELO S (2002) Towards a functional classification of the freshwater phytoplankton. J. Plankton Res. 24 417-428.

ROBARTS RD and ZOHARY T (1984) Microcystis aeruginosa and underwater light attenuation in a hypertrophic lake (Hartbeespoort Dam, South Africa). J. Ecol. 72 1001-1017.

SELKIRK WT (2002) Personal communication. Private Aquatic Environmental Consultancy, Gonubie.

SIMIS SGH, TIJDENS M, HOOGVELD HL and GONS HJ (2005) Optical changes associated with cyanobacterial bloom termination by viral lysis. J. Plankton Res. 27 937-949.
SHAPIRO J (1980) The importance of trophic-level interactions to the abundance and species composition of algae in lakes. Develop. Hydrobiol. 2 105-116.

STARLING F, LAZZARO X, CALVACANTI C and MOREIRA R (2002) Contribution of omnivorous tilapia to eutrophication of a shallow tropical reservoir: evidence from a fish kill. Freshwater Biol. 47 2443-2452.

STRAŠKRABA M (1980) The effects of physical variables on freshwater production: Analyses based on models. In: Le Cren ED and Lowe-McConnell RH (eds.) The Functioning of Freshwater Ecosystems. International Biological Programme (Vol 22). Cambridge University Press, Cambridge. 13-84.

STRAŠKRABA M and TUNDISI JG (1999) Reservoir Water Quality Management. International Lake Environment Committee Foundation, Shiga, Japan. 123 pp.

TOLLRIAN R (1995) Predator-induced morphological defenses: Cost, life history shifts, and maternal effects in Daphnia pulex. Ecol. 76 1691-1705.

VAN GINKEL CE (2004a) Assessment of the National Eutrophication Monitoring Programme, 2003. Internal Report No. N/0000/00/ DEQ/0404 for the Department of Water Affairs and Forestry, South Africa.

VAN GINKEL CE (2004b) Personal communication. Department of Water Affairs and Forestry, Resource Quality Services.

WALMSLEY RD (2000) Perspectives on Eutrophication of Surface Waters: Policy/Research Needs in South Africa. WRC Report No KV129/00. Water Research Commission, Pretoria, South Africa. 60 pp.

WALMSLEY RD and BUTTY M (1980) Guidelines for the Control of Eutrophication in South Africa. Collaborative Report by the Water Research Commission and National Institute for Water Research (CSIR). V\&R Printing Works (Pty) Ltd., Pretoria. 27 pp.

WOMMACK KE and COLWELL RR (2000) Virioplankton: Viruses in aquatic ecosystems. Microbiol. Molec. Biol. Rev. 64 69-114.

ZOHARY T and ROBARTS RD (1989) Diurnal mixed layers and the long-term dominance of Microcystis aeruginosa. J. Plankton Res. 11 25-48.

ZOHARY T and ROBARTS RD (1990) Hyperscums and the population-dynamics of Microcystis aeruginosa. J. Plankton Res. 12 423432 . 